\title{
Anthropos' Smartness as Pillar for Anthropo-Social and Economic Development: Case of Sanitation in Mbuganzeri Model Village, Rweru Sector in Bugesera District (2016-2017)
}

\author{
Father Dr. Hakizimana Lucien
}

Department of Social Sciences, University of Technology and Arts of Byumba (UTAB), Rwanda

\begin{abstract}
Inhabitants who nowadays live in Mbuganzeri model village used to live in Sharita and Mazane Islands high risks zones in lake Rweru. Open defecation was one of the main causes of diarrhea, which resulted in deaths of many children under the age of 5 every year. Children missed their schooling days due to diarrhea as results of poor sanitation. As there were no health posts in these islands, women in delivering were doomed to death. Such a situation should be improved. The objective of this study was to show that investing in sanitation improving an anthropos' smartness contributes to anthropo-social and economic development. To carry out this research, the quantitative and qualitative methods have been used.
\end{abstract}

The results showed that improved sanitation contributes on anthropo-social and economic development. As indicator of anthropo-social development, poverty reduction has been confirmed by $96 \%$, nutrition improvement by $95 \%$, primary education by $100 \%$, gender equality by $99 \%$, reduction of child mortality by $97,5 \%$, and environmental sustainability by $96 \%$. As indicators of anthropo-economic development, regarding undertaken economic development journey, improvement in working has been confirmed by $100 \%$, in investing $81,5 \%$, in saving $86,5 \%$, in job creation $84 \%$ and in use of ICT in their small business (mainly mobile money) $75,5 \%$. This research aimed to analyze the impacts of an anthropos' smartness on anthropo-social and economic development, determining indicators of smart sanitation on personal, households and community in terms of Rwandan development.

Keywords: Anthropos, Smartness, Socio-Economic Development, Sanitation, Mbuganzeri Model Village, Inhabitants.

\section{INTRODUCTION}

Anthropos ${ }^{11}$ smartness in the context of this research regards people with their achievements in hygienic means. This research entitled "Anthropos' Smartness as Pillar for Antropo-Social and Economic Development: Case Study of Sanitation in Mbuganzeri Model Village, Rweru Sector in Bugesera District 2016-2017", aimed to demonstrate how the creation of healthy and smart infrastructures for people is the basic of anthropo-social and economic development. In October 2013, Smart Africa came out of The Transform Africa Summit organized in Kigali from 10 to 12 May 2017. In this summit "Smart Africa", smartness based on ICT was used and understood as a pillar of economic development. Focusing on sanitation is justified by the fact that smartness without sanitation is impossible and economic development without sanitation is impossible as well.

Mbuganzeri model village, the case of our study, is located in Batima Cell of Rweru Sector, Bugesera District. The village was entirely put in place to accommodate relocated families from Sharita and Mazane islands high risks zones in lake Rweru and to uplift the locals' livelihood in general. Inhabitants from these 2 islands were in the poorest category of Rwandan population. Water supply and sanitation coverage are extended in this village which has been inhabited since $28^{\text {th }}$ June 2016 . The targets were the anthropo-social and economic development. ${ }^{2}$

\footnotetext{
${ }^{1}$ The word anthropos (őv $\left.\theta \rho \omega \pi \circ \varsigma\right)$ is derived from Greek and means man or human.

${ }^{2}$ AMCOW, Water Supply and Sanitation in Rwanda: Turning Finance into Services for 2015 and Beyond. https://wsp.org/sites/wsp.org/files/publications/CSO-rwanda.pdf (Retrieved on 17 June 2017).
} 
If the projection of anthropos' smartness is taking into consideration the sanitation, it is because sanitation and water supply prevent diseases and foster development. Inhabitants save what should be spent in terms of money, time and lives; and they start development journey with working, investing, saving, creating new jobs, etc.

\section{MATERIALS AND MeTHODS}

Mbuganzeri model village has been created with the purpose of improving the life of Rwandan citizens. It is located in Rweru Sector in Bugesera District, Eastern Province. This village has 501 inhabitants. Infrastructures found in that model village are water supply, electricity, health post, schools, market and a Technical and Vocational Center (agakiriro).

To get results of our research, we used oral (interview), and written communication (questionnaire) from the sample of 81 of the above mentioned research population. To understand anthropos' smart achievements in Mbuganzeri model village inhabitants, we distributed questionnaires to a sample of 81 people whose ages range between 18 and 65 years and above, who live in Mbuganzeri model village. $47 \%$ of our respondents were between 18 and 35 ages while $53 \%$ were above 36 ages.

Questions were open and one respondent could give his/her point of view on more than one question. Answers were reported on the concept of sanitation in view of an anthropos' smartness in terms of attaining socio-economic development. To carry out this research, quantitative and qualitative methods were used.

The technique of Alain Bouchard's formula sample size has been combined with the technique of cluster sample. In our case, we considered different groups according to the division of streets in Mbuganzeri model village. According to A. Bouchard when the universe of a survey is inferior or equal to $1,000,000$ of individuals that correspond to the sample of 96 within a marginal errors of $10 \%$ and a precision of $95 \%$ times out of 100 as stated below:

Given N=the height of finished universe

$\mathrm{n}=$ the height of sampling for the finished universe 96

$\mathrm{nc}=$ The corrected sampling

The formula applicable to our study is developed below:

$$
n c=\frac{N \times n}{N+n} \quad n c=\frac{501 \times 96}{501+96}=80.56 \cong 81
$$

A purposive sample helped to select individuals to whom we administrated the questionnaire in base of cluster sample. According to Grinnell and Williams, "purposive sampling is one of the nonprobability sampling technique that is used when we want purposely choose a particular sample"3. Following guidelines of Day R., ${ }^{4}$ interview proceeded face-to-face, as conversation between the researcher and respondents. We used questionnaire and interview as means of data collection.

During the interview four key informants were contacted among them the cell executive Secretary, and 3 officials of Mbuganzeri model village. The key theme of interview was sanitation created for an anthropos' smartness in Mbuganzeri model village which plays a role in anthropo-social and economic development of citizens.

In data collection, questionnaire, with clear and understandable questions, was used. Then we proceeded by analyzing the data from the literature review and the data collected from the field through the questionnaire and interview. We used qualitative and quantitative approaches in organization of data into frequencies and also in their interpretation.

\footnotetext{
${ }^{3}$ William and Grinnell (2011), Introduction to social work research, Leader to Leader, Spring: 2000.

${ }^{4}$ Day, R, (1996). How to write and publish a scientific paper, $4^{\text {th }}$ edition, Cambridge, Cambridge university press: 38 .
} 
After editing, data tabulation was done to establish frequency distribution of the codes and then to calculate the number and the percentage of these codes with the aim of presenting understandable data. ${ }^{5}$ This helped the researcher to show the distribution of responses for each question.

\section{RESULTS OF THE RESEARCH}

\subsection{Sanitation, the Key Achievement for an Anthropos' Smartness}

Sanitation is a hygienic means for promoting health through prevention of human contact with hazards of wastes as well as the treatment and proper disposal of sewage or wastewater what people of Sharita and Mazane Islands high risks zones in lake Rweru were missing before being relocated in Mbuganzeri model village. Here we share the view with R. John McGee et Al. who say that "the way in which men produce their means of subsistence depends first of all on the nature of the actual means of subsistence they find in existence and have to reproduce". ${ }^{6}$ In other words, human realization depends on external factors which the State may establish for its citizens. In 2016, 104 families of more than 400 people $^{7}$ from Sharita and Mazane islands were relocated and settled in this model village, ${ }^{8}$ for improving their lives because, being in the category of the poorest in the country, inhabitants of these islands could not evolve easily anthropo-socially and economically. Considering the sanitation as the main objective at Mbuganzeri village, is to protect and promote human health by providing a clean environment and breaking the cycle of disease. ${ }^{9}$

Referring to items announced by Evans, B., et Al., ${ }^{10}$ which fit with what our respondents revealed, for the good of Mbuganzeri people who have been relocated in this new village, sanitation includes all four of these engineering infrastructure items: excreta management systems reported by $100 \%$ and in this village excreta are also producing biogas for cooking, wastewater management systems reported by $100 \%$, solid waste management systems by $100 \%$, drainage systems for rainwater by $100 \%$, also called stormwater drainage. Here, sanitation is regarded with a systems approach in mind which includes collection/containment, conveyance/transport, treatment, disposal or reuse as said Tilley, E., et Al. ${ }^{11}$

In creating Mbuganzeri model village, the purposes of sanitation were to provide a healthy living environment for everyone, to protect natural resources (such as surface water, groundwater, soil), and to provide safety, security and dignity for people when they defecate or urinate. These model infrastructures are in line with the continued liberation process of transforming Rwandans' lives, ${ }^{12}$ what means that an anthropos' smartness is a vision of the Government of Rwanda. Effective sanitation systems provide barriers between excreta and humans in such a way as to break the disease transmission cycle (for example in the case of fecal-borne diseases). Thus, $100 \%$ of our respondents reported the fighting against fecal-oral disease transmission in Mbuganzeri based on F-diagram of Conant Jeff ${ }^{13}$ : fingers, flies, fields, fluids and food.

\footnotetext{
${ }^{5}$ Moses and Kelton, (1971): Research Methodology, Illinois, Inc, Itasca : 67

${ }^{6}$ R John McGee, Richard L. Warms, (2008): Anthropological Theory: An introductory History, $4^{\text {th }}$ Edition, McGraw-Hill, New York: 57.

${ }^{7}$ Now the village has 501 inhabitants.

${ }^{8} \mathrm{http}: / /$ en.igihe.com/news/president-paul-kagame-inaugurates-rweru-model.html retrieved on 13th July 2017.

${ }^{9}$ SuSanA (2008):Towards more sustainable sanitation solutions - SuSanA Vision Document, Sustainable Sanitation Alliance (SuSanA).

${ }^{10}$ Evans, B., van der Voorden, C., Peal, A. (2009): Public Funding for Sanitation - The many faces of sanitation subsidies. Water Supply and Sanitation Collaborative Council (WSSCC), Geneva, Switzerland: 35.

${ }^{11}$ Tilley, E., \& Al. (2014): Compendium of Sanitation Systems and Technologies (2nd Revised Edition). Swiss Federal Institute of Aquatic Science and Technology (Eawag), Duebendorf, Switzerland.

${ }^{12} \mathrm{http} / / /$ en.igihe.com/news/president-paul-kagame-inaugurates-rweru-model.html Retrieved on 13th July 2017.

${ }^{13}$ Conant, Jeff (2005): Sanitation and Cleanliness for a Healthy Environment (PDF). Berkeley, California, USA: 6 .
} 


\subsection{Types of Sanitation Found at Mbuganzeri Model Village}

For the improvement of an anthropos' smartness, people relocated from Sharita and Mazane islands settled where the entire sanitation system was set up: greywater, stormwater and solid waste management. The following are the types of sanitation systems reported at the new village which received people from Sharita and Mazane islands for their anthropo-social and economic improvement:

Community-Led Total Sanitation (CLTS) found in Mbuganzeri model village is an approach to achieve behavior change by a process of "triggering", leading to spontaneous and long-term abandonment of open defecation practices. This is reported by $100 \%$ in Mbuganzeri village. CLTS takes an approach to Mbuganzeri sanitation that works without hardware subsidies and facilitates communities to recognize the problem of open defecation and take collective action to end this practice.

Dry sanitation is also reported by $100 \%$ of our respondents. The term "dry sanitation" somewhat misleading as sanitation includes hand-washing and can never be "dry". A more precise term would be "dry excreta management". When we speak of "dry sanitation" at Mbuganzeri we mean sanitation systems with dry toilets with urine diversion, in particular the urine-diverting dry toilet (UDDT).

For improvement of the idea of an anthropos' smartness, ecological sanitation in Mbuganzeri model village has been set up. This has been reported by $100 \%$ of our respondents. The systems safely recycle excreta resources to crop production in such a way that the use of renewable resources is maximized up to now with a percentage of $78 \%$.

Nowadays, an anthropos' smartness is not possible if the paradigm of environmental sanitation is ignored. Environmental sanitation increased in Mbuganzeri model village encompasses the control of environmental factors that are connected to disease transmission. This control is insured by $79 \%$ of the total respondents. Solid waste management, water and wastewater treatment were thought when this village was being built.

Improved sanitation: This terminology is the indicator used to describe the target of the Millennium Development Goal on sanitation by the WHO/UNICEF Joint Monitoring Programme for Water Supply and Sanitation. Improved sanitation, the management of human feces at the household level, is reported with the percentage of $100 \%$.

On-site sanitation: On-site sanitation, also called decentralized sanitation, is reported at Mbuganzeri model village by $97 \%$ of our respondents. This one is a system where the treatment of excreta or sewage takes place at the same location where it is generated. Examples are pit latrines and septic tanks found there.

Sustainable sanitation is reported by $100 \%$. As said Walker, in order to be sustainable, a sanitation system has to be not only economically viable, socially acceptable, technically and institutionally appropriate, it should also protect the environment and the natural resources ${ }^{14}$. The entire "sanitation value chain", from the experience of the user, excreta and wastewater collection methods, transportation or conveyance of waste and reuse or disposal is remarkable in Mbuganzeri model village.

Prevented diseases by sanitation remarkable in Mbuganzeri model village: Relevant diseases and conditions prevented by sanitation and hygiene include: Waterborne diseases by $100 \%$, which should contaminate drinking water, diseases transmitted by the fecal-oral route by $100 \%$, infections with intestinal helminths (worms) by $100 \%$. However, people can be infected with soil-transmitted helminths because of surrounding regions. They can be transmitted by eggs present in human faeces which in turn contaminate soil in areas where sanitation is poor. Stunted growth in children and malnutrition is prevented, according to our respondent at the percentage of $100 \%$.

As the idea of an anthropos' smartness refers to the provision of facilities and services for the safe disposal of personal, households and community wellbeing, adequate improved sanitation is a major prevention of disease on personal, households and community level and improving sanitation is known to have a significant beneficial impact on health both in households and across communities.

${ }^{14}$ Walker \& Al. (2013): Global burden of childhood pneumonia and diarrhea, Lancet: 16. 


\subsection{Anthropos' Smartness and Anthropo-Social and Economic Development in Mbuganzeri Model Village}

Development can be defined in a manner applicable to all societies at all historical periods as an upward ascending movement featuring greater levels of energy, efficiency, quality, productivity, complexity, comprehension, creativity, mastery, enjoyment and accomplishment. ${ }^{15}$ Development is a process of social change, not merely a set of policies and programs instituted for some specific results. ${ }^{16}$

Development pace and scope vary according to the stage in which the society is. As Mbuganzeri inhabitants came from islands where they were living in poorest conditions, their development has been evaluated in 3 main stages: physical, vital and mental.

\section{Physical Stage}

The physical stage is characterized by the domination of the physical element of the human personality. Before they arrived at Mbuganzeri model village, 100\% reported that in first days they were preoccupied with bare survival and subsistence. There were a little innovation and change. $90 \%$ reported that land and traditional fishing were the main asset and productive resource during this development stage and wealth was measured by the size of land holdings. Anthropologically, this was their agrarian and feudal phase. After their relocation, their anthropo- social and economic development went with creating other income generating activities.

This development has been favored by sound environmental health conditions created for them as key prerequisite to enhance quality of life, to impact positively on sustainable economic growth and to reduce poverty. $100 \%$ confirmed the trend of their anthropo-social and economic development. This policy on water supply and sanitation infrastructure takes into account the existing National Environmental Health Policy adopted by the Cabinet in July 2008. To increase sanitation coverage the policy can build upon scalable sanitary achievements. ${ }^{17}$

\section{$>$ Vital Stage}

In the perspective of an anthropos' smartness, the vital stage of society is infused with dynamism and change. The vital activities of Mbuganzeri citizens expand markedly as attested by $96 \%$ of our respondents. Keeping in mind the idea of an anthropos' smartness, people became curious, innovative and adventurous. The shifts from interactions with the physical environment to new social interactions between people are attested by $89 \%$, and the trend is ascendant. $81,5 \%$ of our respondents reported that Mbuganzeri inhabitants are modernizing agriculture, the principal source of wealth. $80 \%$ of our respondents attested that the rule of law is becoming more formal and binding, providing a secure and safe environment for business to flourish.

\section{Mental Stage}

For Mbuganzeri inhabitants, the mental development stage has three essential characteristics: practical, social, and political application of mind. In the period of one year they were relocated in this new model village, $84 \%$ of our respondents noticed a practical application of mind that generates many inventions. The anthropo-social application of mind leads to new and more effective types of social organization so that in Mbuganzeri, feast and leisure (some characteristics of anthropo-social and economic development) were reported by $100 \%$ of our respondents. The political application was also reported by $88 \%$. This led Mbuganzeri inhabitants to empowerment in exercising political and human rights in a free and democratic manner in their village.

\footnotetext{
${ }^{15}$ Jacobs, Garry and Asokan N., (1999) "Towards a Comprehensive Theory of Social Development" In Human Choice, World Academy of Art \& Science, USA: 152.

${ }^{16}$ International Commission on Peace and Food (1994) Uncommon Opportunities: An Agenda for Peace and Equitable Development, Zed Books, UK: 163.

${ }^{17}$ Ministry of Infrastructure, (2010): National Policy \& Strategy for Water Supply and Sanitation Services http://www.rura.rw/fileadmin/docs/Board_Decisions/WATSAN_Policy_Strategy.pdf (Retrieved on 20 June 2017).
} 
Improving access to water and sanitation has various impacts on the overall anthropo-social and economic development of Mbuganzeri inhabitants: amongst other things, it contributes to poverty reduction (by the creation of new jobs) alleviating hunger, improving health and primary education, and environmental sustainability. Corroborating with Dangour, A.D et Al., ${ }^{18}$ according to the fundamental role of water in people's life, $100 \%$ of our respondents reported that the improved access to water and sanitation also contributes to a number of other development goals. Expanding access to water and sanitation is a moral and ethical imperative.

The Millennium Development Goals 7 stipulated to improve environmental sustainability by integrating sustainable development in country policies, by reducing the biodiversity loss, by halving the proportion of people without access to safe water and sanitation and by improving lives of at least 100 million slum dwellers. According to UNDP, overall human development is more closely linked to access to water and sanitation than any other development driver, including spending on health or education, and access to energy services. ${ }^{19}$

\section{DISCUSSION OF FINDINGS}

In the context of our research, development is seen as all manifest of change occurred in living conditions and standards of people due to improved smartness in daily life. To deepen this study, questions were asked to 81 people who live in Mbuganzeri model village and interview was given to four keys informants.

\subsection{Infrastructures and Activities to Improve Anthropos' Smartness in Mbuganzeri Model Village}

Firstly, statistics showed that $93.8 \%$ confirmed that improved sanitation infrastructures created for an anthropos' smartness improved anthropo-social and economic development of Mbuganzeri model village. Availability of septic tanks was attested by $100 \%$ while $90 \%$ of the respondents reported waste management and behavior change in personal hygiene. $49 \%$ of our respondents reported availability of antiseptic products as indicators of improved anthropos' smartness in terms of anthropo- social and economic development in Mbuganzeri model village. This small percentage is due to the fact that Mbuganzeri inhabitants were supposed to buy themselves these antiseptic products after one year of settlement. The sensitization is going on.

Secondly, our respondents confirmed the following infrastructures and activities as improvement of anthropos' smartness in Mbuganzeri village: 100\% of research participants reported access to latrines that meet hygienic standards; $100 \%$ reported access to potable water; $100 \%$ reported the construction of toilets in every household; $100 \%$ underlined public education about sanitation measures; while $74 \%$ of research participants reported appropriate way to treat and evacuate waste as activities and strategies to improve sanitation in Mbuganzeri model village. Unanimously, the results from interview showed that Mbuganzeri model village tries to ensure that latrines are clean. One of our key informants in Mbuganzeri model village emphasized: "in this village we care about using antiseptic cleaning products in toilet and treatment of drinking water for Mbuganzeri inhabitantsis secured". Indeed, in Mbuganzeri village is installed a public filter for drinking water. She mentioned also that the village has a way of burning trashes in order to ensure a clean environment.

Finally, the following activities were reported to increase an anthropos' smartness in Mbuganzeri model village: $94 \%$ of respondents supported the change in wellbeing brought by health services; 95\% reported infections and spread of diseases prevention; $96 \%$ reported maternal and child mortality reduction while $97,5 \%$ reported that reduction of time and money spent in hospital due to improved sanitation. After presenting, analyzing and interpreting the results of our research, the following are indicators of sanitation in terms of anthropo-social and economic development.

${ }^{18}$ Dangour, A.D et Al. (2013): Interventions to Improve Water Quality and Supply, Sanitation and Hygiene Practices, and Their Effects on the Nutritional Status of Children, Chichester: John Wiley \& Sons.

19 UNDP (2010): WASH Programme: Country Sector Assessments Volume 2. Governance, Advocacy and Leadership for Water, Sanitation and Hygiene. New York: United Nations Development Programme. 
Anthropos' Smartness as Pillar for Anthropo-Social and Economic Development: Case of Sanitation in Mbuganzeri Model Village, Rweru Sector in Bugesera District (2016-2017)

\subsection{Indicators of an Anthropos' Smartness in Terms of Anthropo-Social and Economic Development in Mbuganzeri Model Village}

Interviewees highlighted that as sanitation was strengthened and implemented in a proper way in Mbuganzeri model village, people no longer waste their time at the hospital, don't spend the money paying medicine so that this money is used for their anthropo-social and economic development.

Here are some key development issues which are addressed by improved access to sanitation:

\begin{tabular}{|c|c|c|}
\hline \multicolumn{3}{|c|}{ Indicators of anthropo-social development } \\
\hline Indicators of anthropo-social development & Frequency & Percentage \\
\hline 12 Years Basic Education & \multirow{2}{*}{81} & $100 \%$ \\
\hline Gender Equality & & $99 \%$ \\
\hline Child Mortality Reduction & 80 & $97,5 \%$ \\
\hline Environmental Sustainability & 78 & $96 \%$ \\
\hline $\begin{array}{l}\text { Poverty reduction } \\
\text { Nutrition }\end{array}$ & \multirow{2}{*}{$\frac{78}{77}$} & $96 \%$ \\
\hline \multirow[t]{2}{*}{ Nutrition } & & $95 \%$ \\
\hline & \multicolumn{2}{|c|}{$\begin{array}{l}\square 12 \text { Years Basic Education } \\
\square \text { Gender Equality } \\
\square \text { Child Mortality Reduction } \\
\square \text { Environmental Sustainability } \\
\square \text { Poverty reduction } \\
\square \text { Nutrition }\end{array}$} \\
\hline
\end{tabular}

Source: Primary data, July 2017

\begin{tabular}{|l|l|l|}
\hline \multicolumn{3}{|c|}{ Indicators of anthropo-economic development } \\
\hline Indicators of anthropo-economic development & Frequency & Percentage \\
\hline Improvement in Working & 81 & $100 \%$ \\
\hline Improvement in Saving & 70 & $86,5 \%$ \\
\hline Improvement in Job Creation & 68 & $84 \%$ \\
\hline Improvement in Investing & 66 & $81,5 \%$ \\
\hline $\begin{array}{l}\text { Improvement in Use of ICT in their Small } \\
\text { Business (mainly Mobile Money) }\end{array}$ & 61 & $75,5 \%$ \\
\hline
\end{tabular}

Source: Primary data, July 2017

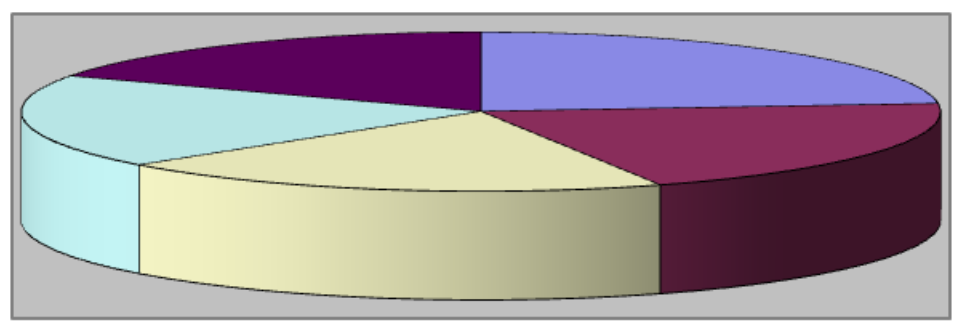

口Improvement in Working
almprovement in Saving
almprovement in Job Creation
IImprovement in Investing
Improvement in Use of ICT in their Small
Business (mainly Mobile Money)

Fig. Indicators of anthropo-economic development

After one year of their settlement in Mbuganzeri model village, integration in 12 years basic education has been reported. In Mbuganzeri village, illness related to sanitation that was causing school dropouts was reduced, including injuries from water-carrying and school attendance was improved especially for girls. $100 \%$ of our respondents attested this. This is a long term investment for households and for the country.

Gender equality: Sanitation facilities closer to home put women and girls at less risk for sexual harassment and assault while gathering water. Community-based organizations for sanitation improved women's social capital what in return generate income for households. This was confirmed 
by $99 \%$ of our respondents. Reduced time, health, and care-giving burdens from improved sanitation services give women more time for productive endeavors, adult education, empowerment activities, and leisure.

Child mortality reduction: Mothers with improved sanitation services are better able to care for their children because they have fewer illnesses and devote more time to their children's health ${ }^{20}$. In Mbuganzeri village, this case was reported by $97,5 \%$ of our respondents. According to reports from $\mathrm{UNICEF}^{21}$, improved sanitation reduces infant and child morbidity and mortality.

Environmental sustainability: As said Albuquerque, C., adequate treatment and disposal of excreta and wastewater contribute to better ecosystem management and less pressure on freshwater resources $^{22} .96 \%$ of our respondents attested that improved sanitation reduces flows of human excreta into waterways, helping to protect human and environmental health.

Poverty was reduced as confirmed by $96 \%$ of our respondents and the trend is ascendant. Household livelihood security is depending on their health, hence adults who are not ill or who don't have sick children to care for are more productive.

Nutrition improvement was attested by $95 \%$ of our respondents. After they were relocated to Mbuganzeri model village, people are economically more productive. Healthy people, as they said, are better able to absorb the nutrients in food than those suffering from poor sanitation particularly worms.

Regarding anthropo-economic development, undertaken development journey was confirmed by $100 \%$ in working improvement. After the settlement in Mbuganzeri model village, inhabitants feel healthy and the yield of their work is increasing. 86, 5\% of our respondent attested the saving undertaken and its improvement in Mbuganzeri village. This is going on with the culture of job self creating where $84 \%$ of our respondents confirmed job creation. $81,5 \%$ are investing in new activities which supplement the agriculture and as they reported, the development made in one year would increase more in the future. Through mobile money system, the rate of the use of ICT in business was reported by $75,5 \%$ of our respondents.

\subsection{Impacts of Anthropos' Smartness on Socio-Economic Development in Mbuganzeri Model Village}

The care given in view of anthropos' smartness through infections and spread of disease prevention, reduction of time and money spent in hospital due to poor sanitation, ability to provide safe care and presenting serious health risks to those seeking treatment, improved maternity services impact upon the anthropo- social and economic development in Mbuganzeri model village. As said Hutton, G. and Haller, L., improving sanitation services has substantial economic benefit: WHO estimated some years ago that each $\$ 1$ invested would yield an economic return of between $3 \$$ and $4 \$$, depending on the region. UNDP estimated recently that an investment in water supply yields an average economic return of $\$ 4.4$ to $\$ 1$ and investment in sanitation a return of $\$ 9.1$ to $\$ 1 .^{23}$

In the same line, Hutton, G.; Haller, said that the health-related costs avoided would reach $\$ 7.3$ billion per year, and the annual global value of adult working days gained because of less illness would rise to almost $\$ 750$ million. ${ }^{24}$ In Mbuganzeri model village, with improved wellbeing resulting from the relocation's inhabitants to a site with improved sanitation, the installation of piped water supply near houses, and latrines annexed to every home yield significant savings.

\footnotetext{
${ }^{20}$ Spears, D. (2013): How much International Variation in Child Height Can Sanitation Explain? Washington: The World Bank Water and Sanitation Program (WSP).

${ }^{21}$ UNICEF; WHO (2012): Progress on Drinking Water and Sanitation, New York/Geneva: United Nations International Children's Emergency Fund (UNICEF)/World Health Organisation (WHO).

${ }^{22}$ Albuquerque, C. (2013): Report of the Special Rapporteur on the Human Right to Safe Drinking Water and Sanitation, Geneva: Office of the United Nations High Commissioner for Human Rights (OHCHR).

${ }^{23}$ Hutton, G.; Haller, L. (2004): Evaluation of the Costs and Benefits of Water and Sanitation Improvements at the Global Level. Geneva: World Health Organisation (WHO) (Retrieved on 25 ${ }^{\text {th }}$ April.2017).

${ }^{24}$ Hutton, G.; Haller, L. (2004): Evaluation of the Costs and Benefits of Water and Sanitation Improvements at the Global Level. Geneva: World Health Organisation (WHO) (Retrieved on 25 ${ }^{\text {th }}$ April.2017).
} 
The cell executive secretary estimated that this water supply adequate sanitation are yielding economic gains equivalent to what Government of Rwanda spent to these Mbuganzeri inhabitants in 3 previous years when they were still in islands as they were in the category of poorest in Rwanda who must be helped in everything by the Government. Cross, P. and Coombes, Y. indicate that premature mortality and other health-related impacts of inadequate sanitation were the most costly with $72 \%$ of total impacts, followed by time lost to access to sanitation facilities or sites for defecation with $20 \%$, and drinking water-related impacts with 7.8\%. In Rwanda and all around the World, the provision of basic sanitation can have various, significant impacts on hunger alleviation, health, education or environmental conditions. This is needed to protect valuable ecosystem services, such as biodiversity, fish habitats and pollination. ${ }^{25}$

The research shows that every US $\$ 1$ spent on sanitation brings a $\$ 5.50$ return by keeping people healthy, smart and productive. Dirtiness on the other side in the context of poor sanitation, costs the Government of Rwanda. It spends $2.3 \%$ of its GDP in improving sanitation infrastructures. Therefore, doing nothing in terms of improved sanitation is costly ${ }^{26}$. Even though over $80 \%$ of the country's population has access to latrines, only $8 \%$ of these meet hygienic standards ${ }^{27}$.

\section{Conclusion}

This research was about anthropos' smartness as pillar for anthropo-social and economic development. Besides the literature review which provided us with insights from other authors regarding this topic, using questionnaire and interview we collected data which were analyzed and interpreted.

Thus, as results, respondents gave their point of view about the impact of an anthropos' smartness on anthropo-social and economic development as the statistics showed. 94\% of respondents supported that they have trust in health after their relocation; 95\% reported that preventing infections and spread of diseases is noticed in Mbuganzeri model village, and maternal and child mortality reduction was reported by $97,5 \%$ of our respondents, while $97,5 \%$ reported that reduction of time and money spent in hospital due to poor sanitation and improved welfare of households is an impact of sanitation in Mbuganzeri village. Undertaken economic development journey was confirmed by $100 \%$ in working improvement, $81,5 \%$ in investing, $86,5 \%$ in saving, $84 \%$ in job creation and $75,5 \%$ in the use of ICT in small business.

Interviewees highlighted that sanitation, characteristic of an anthropos' smartness, strengthened in a proper way in Mbuganzeri model village is increasing the anthropo-social and economic development of Mbuganzeri inhabitants and reduced diseases which could affect Mbuganzeri citizens. To conclude, as all research participants agreed on the relevance of our research, we confirmed that an anthropos' smartness has a considerable impact on anthropo-social and economic development and Smart Africa launched in October 2013 in The Transform Africa Summit organized at Kigali in Rwanda, held for the second time in May 2017 with the theme "Smart Africa", smartness based on ICT must be accompanied by smartness based on sanitation.

\section{REFERENCES}

[1] Albuquerque, C. (2013): Report of the Special Rapporteur on the Human Right to Safe Drinking Water and Sanitation, Catarina de Albuquerque: Geneva.

[2] AMCOW, Water Supply and Sanitation in Rwanda: Turning Finance into Services for 2015 and Beyond. https://wsp.org/sites/wsp.org/files/publications/CSO-rwanda.pdf (Retrieved on 17 June 2017)

[3] Caroline Kayonga (2007): Towards universal health coverage in Rwanda. Summary notes from briefing Brookig Institution Washington D.C.

\footnotetext{
${ }^{25}$ Cross, P.; Coombes, Y. (2013): Sanitation and Hygiene in Africa: Where do we Stand? London: International Water Association (IWA).

${ }^{26}$ WHO/UNICEF. Economic impact: World Bank, www.sanitationdrive2015.org (Retrieved on $3^{\text {rd }}$ July 2017).

27 UNDP (2010): WASH Programme: Country Sector Assessments Volume 2. Governance, Advocacy and Leadership for Water, Sanitation and Hygiene. New York: United Nations Development Programme. (Retrieved on $3^{\text {rd }}$ July 2017).
} 
[4] Conant, Jeff (2005): Sanitation and Cleanliness for a Healthy Environment. Berkeley: California.

[5] Cross, P.; Coombes, Y. (2013): Sanitation and Hygiene in Africa: Where do we Stand? Analysis from the Africa San Conference, Kigali, Rwanda. London: International Water Association (IWA).

[6] Dangour, A.D \& Al. (2013): Interventions to Improve Water Quality and Supply, Sanitation and Hygiene Practices, and Their Effects on the Nutritional Status of Children, Chichester: John Wiley \& Sons.

[7] Day, R, (1996): How to write and publish a scientific paper, $4^{\text {th }}$ edition, Cambridge, Cambridge University Press.

[8] Evans, B., Van der Voorden, C., Peal, A. (2009): Public Funding for Sanitation - The many faces of sanitation subsidies. Water Supply and Sanitation Collaborative Council (WSSCC): Geneva.

[9] http://en.igihe.com/news/president-paul-kagame-inaugurates-rweru-model.html (retrieved on 13th July 2017).

[10] http://en.igihe.com/news/president-paul-kagame-inaugurates-rweru-model.html (Retrieved on 13th July 2017).

[11] Hutton, G.; Haller, L. (2004): Evaluation of the Costs and Benefits of Water and Sanitation Improvements at the Global Level, World Health Organization: Geneva.

[12] International Commission on Peace and Food, (1994): Uncommon Opportunities: An Agenda for Peace and Equitable Development, Zed Books: UK.

[13] Jacobs, Garry and Asokan N. (1999): "Towards a Comprehensive Theory of Social Development”. In: Human Choice, World Academy of Art \& Science: USA.

[14] John McGee R., Richard L. Warms (2008): Anthropological Theory: An introductory History, $4^{\text {th }}$ Edition, McGraw-Hill: New York.

[15] Ministry of Infrastructure, (2010): National Policy \& Strategy for Water Supply and Sanitation Services http://www.rura.rw/fileadmin/docs/Board_Decisions/WATSAN_Policy_Strategy.pdf (Retrieved on 20 June 2017).

[16] Moses and Kelton (1971): Research Methodology, Illinois: Itasca.

[17] Spears, D. (2013): How much International Variation in Child Height Can Sanitation Explain? Washington: The World Bank Water and Sanitation Program (WSP).

[18] Tilley, E.,\& Al. (2014): Compendium of Sanitation Systems and Technologies (2nd Revised Edition). Swiss Federal Institute of Aquatic Science and Technology: Duebendorf, Switzerland.

[19] UNDP (2010): WASH Programme: Country Sector Assessments Volume 2. Governance, Advocacy and Leadership for Water, Sanitation and Hygiene. New York: United Nations Development Programme. (Retrieved on $5^{\text {th }}$ May 2017).

[20] UNICEF; WHO (2012): Progress on Drinking Water and Sanitation. New York/Geneva: United Nations International Children's Emergency Fund (UNICEF)/World Health Organisation. Walker \& Al. (2013): Global burden of childhood pneumonia and diarrhea: Lancet.

[21] WHO/UNICEF: Economic impact: World Bank. www.sanitationdrive2015.org (Retrieved on $16^{\text {th }}$ June 2017). William and Grinnell (2011): Introduction to social work research, Leader to Leader, Spring. 